\title{
PREPARING SCHOOL GRADUATES FOR THE LABOUR MARKET
}

\author{
Mária Nováková ${ }^{1}$ \\ Silvia Capíková ${ }^{2}$
}

DOI: https://doi.org/10.31410/ITEMA.2020.177

\begin{abstract}
Despite their determination to work and build their careers, school graduates are not sufficiently prepared to look for work and the opportunities to search a job. In most cases they are well prepared in theory and language and are literate in modern technologies. Their biggest handicap is the lack of practical skills and work experience. At the same time, graduates have to face the challenges of accelerated globalization and digitization. It is necessary to find answers to questions about what professional knowledge, practical skills, attitudes and values will be shaped by today's graduates and how education systems can develop the required knowledge and skills. The ambition of our contribution is to identify the main disparities that must be overcome in order to achieve the goal of the country's economic development strategy, in which the education system must inevitably correspond to the labour market requirements.
\end{abstract}

Keywords: Labour market, School graduates, Skills.

\section{INTRODUCTION}

A ccelerated globalization and, as a result, the pandemic crisis are bringing about societal change and have affected a wide range of areas from industry to technical standardization, security, education system, science, research to the labour market or the social system.

The reality of the national labour market, but also of the global labour market, is one of the most complex objects of research. It is absolutely essential that the theory, based on careful observation, analysis and generalization, comes up with new recommendations for improving the organization of the education system and for implementing a successful social policy.

The subject of the paper is mainly the analysis and research of professional competencies, which are crucial and useful for the labour market.

\section{PROFILE OF YOUNG PEOPLE APPLYING FOR JOBS}

There is no doubt that each generation has certain specifics that are only a manifestation of the dominants of historical development.

While previous generations have become accustomed to the stability and security of employment, the current driving force prefers greater flexibility in working conditions and

1 Faculty of Law, Comenius University in Bratislava, Šafárikovo námestie 6, 81000 Bratislava, Slovak Republic

2 Faculty of Medicine, Comenius University in Bratislava, Špitálska 24, 81372 Bratislava, Slovak Republic 
favours of "freelance" work. Their goal in the work process is primarily to achieve a work-life balance. $^{3}$

\section{EMPLOYERS' REQUIREMENTS}

Digitization, automation and robotics are processes that began to have a significant impact on the labour market before the pandemic crisis.

However, it was not until the onset of the pandemic crisis, which is a global public health crisis that the digitization of the private and public sectors accelerated enormously.

Rapid technological progress raises a number of concerns and panics about the threat to the existence of today's jobs and at the same time about the uncertainty of the unknown possibilities of shaping future labour markets.

Enormously changing technological changes must adapt employers' requirements for new jobs.

At present, it is unthinkable that an employee does not have technological and digital skills. Employers also appreciate soft skills, such as analytical thinking, communication, creativity, the ability to process complex information. Employers are also placing increasing emphasis on social skills.

\section{ALTERNATIVES TO PREPARING SCHOOL GRADUATES FOR THE LABOUR MARKET}

Global challenges also require global solutions to prepare school graduates for the global labour market.

Accredited training institutions must be prepared to flexibly reflect the needs of the labour market.

The education system must support the adaptation of theoretical knowledge, skills and qualifications to demand and job opportunities. This means that it must facilitate the possibility of the traditional transition from school to work.

In this regard, it is extremely important not only at the national, but also at the global level to support research in the field of shaping the work environment, especially research that is aimed at identifying promising study programs shaping graduates.

Educational institutions are expected to develop competencies that are focused primarily on verbal communication, analytical critical thinking, creativity, complex problem-solving in teamwork, the ability to establish relationships, etc. These skills are referred to in practice as soft skills. ${ }^{4}$

3 NEVICKÁ, D.: Graduate and Digitization of the Labour Market. Reviewed. In: Labour law in digital form: conference with international participation. -: $1^{\text {st }}$ ed. ISBN 978-80-7502-259-2. - Prague: Printing house Leges, 2017.-p. 216-226 ((Theoretical)).

4 NEVICKÁ, D.: Graduate and Digitization of the Labour Market. Reviewed. In: Labour law in digital form: conference with international participation. -: $1^{\text {st }}$ ed. ISBN 978-80-7502-259-2. - Prague: Printing house Leges, 2017.-p. 216-226 ((Theoretical)). 
The preparation of a quality graduate proving successful on the labour market depends not only on the acquisition and development of soft skills, but above all on vocational training and the acquisition of practical skills, which we call hard skills.

However, without real practice, it is not possible to create space in the academic environment to acquire sufficient and suitable practical skills.

Within academic education, there is an urgent need to develop competencies in a real work environment. It is necessary to create a space for mutual cooperation of educational institutions with institutions in a real work environment. The close cooperation and mutual interaction of these two entities is a sufficient guarantee of quality preparation of young people for proving successful in the work environment.

Such close cooperation can be seen in the medical fields, but in other fields the acquisition of practical skills is more of a formal nature. This negative phenomenon in the process of acquiring practical skills is unacceptable, and there are alternatives to reverse this.

One possible solution can be given for illustration. Every individual can find himself in an unfavourable life situation, which will change his life by 180 degrees in a few seconds. As a result, his status changes from an economically active member of society to a socially stigmatized and socially excluded one. The handicap is all the greater because the current generation professes the values of profit and capital. The given trend is striking on social networks, where only those who present themselves as young, beautiful and rich are successful. The task of every developed society should be to strive for the greatest possible socialization of disabled people, in the form of community rehabilitation. The aim of community rehabilitation is the renewal or development of physical abilities, mental abilities and work abilities of an individual in an unfavourable social situation and support of his integration into society.

If, as a result of a sudden injury or illness, an individual finds himself in a state of severe or permanent impairment of the body's functional ability, it legally requires care that falls within the health care system. Depending on the type and extent of the damage to health, the disabled individual will be provided with an adequate form of institutional health care. The fact that the form of institutional health care is limited in time by health insurance companies can be assessed negatively. It is often the case that hospitalization is terminated even in untreated patients. After the end of hospitalization, i.e. the institutional care, the patient is discharged to home treatment. By ending the health care process, the disabled person does not become selfsufficient. With a disability, special needs and dependence on the help of another person occur at the same time. A disabled person requires another form of care, namely social care.

Entry into the social care system is significantly more complicated than entry into the health care system. Social care is not provided immediately, but presumes an administrative initiative from the disabled person or another person on which the disabled person is dependent. It represents an enormous bureaucratic, time and financial burden for the disabled, but also for his loved ones, who are not yet emotionally balanced with a permanently unfavourable social situation.

Depending on the unfavourable social situation and the degree of dependence on the assistance of another natural person, the disabled person has the right to choose a social service and the form of its provision. Dependence on social services is proved by a valid decision on 
dependence on social services, while the issuance of a decision is preceded by a lengthy process of health assessment activity and subsequently social assessment activity.

There is an unnecessarily long vacuum between the end of the provision of health care and the start of the provision of social care, which deepens the hopeless situation of the disabled person and his loved ones. They lack orientation in the material, personal and territorial scope of social regulations. They have no experience of which institutions to turn to or what form of assistance to ask for. Nor are there isolated cases where disabled people have to cope with the reluctance and impatience of the staff of the institutions. ${ }^{5}$ Under the influence of such unpleasant circumstances, people with disabilities often have suicidal tendencies.

There is still a tendency in society to help the disabled in the form of one-time in-kind and monetary benefits, associated with a spectacular media presentation. Of course, financial assistance is also extremely important, but this method of assistance is not permanent and is counterproductive for people with disabilities. They are pushed into a passive position, thus eliminating their ambition to cope with the situation and the ability to handle self-service activities as much as possible. ${ }^{6}$

In this case, space is opening up for community rehabilitation, which could fill the gap in the absence of care for a disabled person, due to the time-consuming transition from the health care system to the social care system. The social need is essentially calling for the creation of some kind of community rehabilitation centres, in which disabled people would be placed, who, although the process of providing institutional health care has ended, still require some form of outpatient specialized care for general treatment. It is necessary to emphasize the fact that, due to their disability, they also have special needs, while they are dependent on the help of another natural person. The role of community rehabilitation centres would be to ensure the provision of health care and start the process of providing social care, until their complete transition to the social care system. In community rehabilitation centres in particular, people with disabilities should acquire, as far as possible, self-service skills. They would acquire practical skills in simulated home conditions, which means that they would acquire them under professional supervision in specially adapted flats. The benefit for disabled people would be the fact that during their stay in the community rehabilitation centre, the professional staff would also ensure a suitable construction of their household. The length of stay in a community rehabilitation centre would not be limited in time and would depend on the physical and mental abilities of the disabled person. Bridging the two systems would ensure the continuity of care for the disabled.

It can be assumed that, as with the health care and social care system, the biggest obstacle to providing community rehabilitation will be the lack of funding sources, but this would not be so significant if the organization of community rehabilitation were linked to the need for practical teaching in academic education. Community rehabilitation centres would create specialized teaching facilities, where practical training of students would be carried out in order

5 BEŇO, P.\& CAPÍKOVÁ, S. (2014). Social debarierization in healthcare from the point of view of patients with hearing impairment. In: The patient in the health system and in society. Proceedings of the international scientific conference held on December 11, 2012 in Bratislava. Bratislava: Section of Sociology of Health of the Slovak Sociological Society at the Slovak Academy of Sciences. p.81. ISBN 978-80-85447-22-4.

6 TRELOVÁ, S.: A tool to support the employment of people with disabilities in the labour market. In: Legal and economic aspects of long-term unemployment in the Slovak Republic 2014. Proceedings of a scientific conference held on October 24, 2014 organized by the research team of the project VEGA reg. no. 1/0935/12. p. 114. ISBN 978-80-7160-388-7. 
to acquire professional competence to perform professional work activities in the relevant field of study and, as a result, the centres would have to go through the accreditation process. Practical teaching of students in community rehabilitation centres would be mutually beneficial. A meaningful space for acquiring practical skills in the chosen field of study is offered to students of medical faculties, nursing faculties, construction faculties, theological faculties, law faculties, etc. For example, students of construction faculties would participate in the preparation of proposals, but also the implementation of construction modifications of households of disabled people, students of law faculties would provide advice and overall administration resulting from relevant legislation, etc. High school students would also find application for practical training.

Through a form of community rehabilitation, one of the holes in the social network through which disabled people fall and "drown in the mud" of social exclusion would be "repaired."

This form of care provision could be used not only by disabled people, but also by other natural persons in an unfavourable social situation.

\section{VULNERABLE PERSONS}

In connection with the issue of training graduates employed in the labour market, the unemployed are demonstrated as a specific problem. These are vulnerable people who have achieved only low qualifications as a result of the accumulation of social disadvantages. The impact of the social background on the initial results of their education and on the level of their skills is not negligible. Social inequality and inequality of opportunity are a particular problem for this workforce. Even a tool of further education aimed at increasing the qualification or retraining of low-skilled people is proving impossible. There is virtually no impact on vulnerable groups who suffer from cumulative social disadvantages, with the emphasis that they do not even register as jobseekers. ${ }^{7}$ This negative trend signals an acute risk factor for economic growth. More needs to be done to develop a comprehensive long-term strategy to activate vulnerable low-skilled graduates to engage in further education.

\section{ACTIVE LABOUR MARKET MEASURES}

It must be stated that active labour market measures in relation to vulnerable and disadvantaged jobseekers are unsystematic and ineffective. They can be described as inactive or passive without any exaggeration. They do not create space for job seekers to be active in solving their social situation, or provide opportunities for their self-realization, but they have a demotivating effect on them. ${ }^{8}$

Not only does the concept of social inclusion of jobseekers fail, but the unprecedented waste of public funds spent on inefficient further education can be assessed very negatively. The implementation of such non-systemic measures does not take into account the needs of practice and certainly has no impact on employment growth.

7 ŠTEFÁNIK, M. et al. LABOUR MARKET IN SLOVAKIA 2019+. Centre of Social and Psychological Sciences, Slovak Academy of Sciences (CSPS SAS), Institute of Economic Research, Slovak Academy of Sciences (IER SAS), Faculty of Arts, Comenius University in Bratislava (FA CU): ŠEVT, as, Bratislava, Bratislava 2018, ISBN 978-80-7144-296-7

8 HAMULÁK, J. Legal or illegal. Legal-theoretical and application problems of illegal work and illegal employment in the Slovak Republic. - $1^{\text {st }}$ ed. - Bratislava: Wolters Kluwer, 2017. - 139 p., ISBN 978-808168-688-7 


\section{CONCLUSION}

Accelerated digitization and the advent of new technologies should be accompanied by innovation in the education system, which would enable the comprehensive development of the theoretical and practical skills of future jobseekers. Only highly qualified and educated individuals with skills that are applicable in the digital economy will have a chance to enter the labour market.

Educational institutions need to be more active and more flexible in adapting their curricula to the demand for current and future technological skills. It is more than desirable to ensure the development of digital skills at all levels of the education system, including lifelong education programs.

The pandemic crisis made it impossible for students to attend full-time teaching, and educational institutions had to transform their teaching to distance education. As a result, measures need to be taken to ensure that the vulnerable people also cope with the distance form of teaching. As such, it is necessary for the public and private sector to create and ensure access to technical and electronic equipment for economically and socially disadvantaged people, who unfortunately include the teachers themselves.

The health care system, the social care system and the education system are considerably materially, technically, personally and financially undersized. Their combination would at least partially solve their undersizing and at the same time the requirement would be met of acquiring quality theoretical knowledge, but also practical skills of future job seekers. One of the goals of achieving and maintaining a high socio-economic level of society is to eliminate the various types of disadvantages suffered by its members. It is essential to strive for a system that promotes employment and enables development at regional level. As a result, the integration of jobseekers, in particular disadvantaged jobseekers, who are most at risk of social exclusion, could also be implemented.

\section{REFERENCES}

BEŇO, P. \& CAPÍKOVÁ, S. (2014). Social debarierization in healthcare from the point of view of patients with hearing impairment. In: The patient in the health system and in society. Proceedings of the international scientific conference held on December 11, 2012 in Bratislava. Bratislava: Section of Sociology of Health of the Slovak Sociological Society at the Slovak Academy of Sciences. Pp.72-84. ISBN 978-80-85447-22-4.

HAMULÁK, J. (2017). Legal or illegal. Legal-theoretical and application problems of illegal work and illegal employment in the Slovak Republic. - $1^{\text {st }}$ ed. - Bratislava: Wolters Kluwer. 139p., ISBN 978-80-8168-688-7.

NEVICKÁ, D. (2017). Graduate and Digitization of the Labour Market. Reviewed. In: Labour law in digital form: conference with international participation. -: $1^{\text {st }}$ ed. ISBN 978-807502-259-2. - Prague: Printing house Leges. pp. 216-226 ((Theoretical)).

ŠTEFÁNIK, M. et al. (2018). LABOUR MARKET IN SLOVAKIA 2019+. Centre of Social and Psychological Sciences, Slovak Academy of Sciences (CSPS SAS), Institute of Economic Research, Slovak Academy of Sciences (IER SAS), Faculty of Arts, Comenius University in Bratislava (FA CU): ŠEVT, a.s. Bratislava, Bratislava 2018, ISBN 978-807144-296-7.

TREL'OVÁ, S. (2014). A tool to support the employment of people with disabilities in the labour market. In: Legal and economic aspects of long-term unemployment in the Slovak 
Republic 2014. Bratislava: Comenius University in Bratislava. pp. 114-119. ISBN 97880-7160-388-7.

Act No. 131/2002 Coll. on Higher Education Institutions and on Amendments to Certain Acts, as amended.

Act No. 553/2003 Coll. on Remuneration of Certain Employees in the Performance of Work in the Public Interest and on Amendments to Certain Acts as amended.

Act No. 576/2004 Coll. on Health Care, Services Related to the Provision of Health Care and on Amendments to Certain Acts, as amended.

Act No. 578/2004 Coll. on health care providers, health care workers, professional organizations in health care and on the amendment of certain laws as amended.

Act No. 448/2008 Coll. on social services and on the amendment of Act No. 455/1991 Coll. on Trade Licensing (Trade Licensing Act) as amended.

Government Regulation No. 296/2010 Coll. on professional competence for the performance of the medical profession, the method of further education of medical staff, the system of specialized departments and the system of certified work activities, as amended.

Decree of the Ministry of Health of the Slovak Republic No. 84/2016 Coll., which establishes the determining features of individual types of medical facilities. 